\title{
ARTHUR WALEY AND AMY LOWELL: A NO'TE
}

\author{
BY FRANCIS A. JOHNS
}

Mr. Johns is Research Bibliographer in Alexander Library

RTHUR Waley's translations from the Chinese attracted wide-
spread attention when some of them were printed in 1917 in
the Bulletin of the School of Oriental Studies. ${ }^{1}$ More followed in other periodicals, both British and American, and in July I9I 8 his collection $A$ Hundred and Seventy Chinese Poems was published by Constable. It was shortly to be called "one of the most memorable books of recent years," a judgment amply confirmed by subsequent critics. ${ }^{2}$ Alfred Knopf inquired soon afterwards about an American edition. ${ }^{3}$ It came out in May I919, and an advertisement for the book appeared in The New Republic of May 3I quoting from an endorsement which Knopf had obtained from Amy Lowell, and which she authorized him to use in his publicity. (Miss Lowell's letter, dated 22 May I9I9, was recently acquired by the Alexander Library on the William Allen Chapman Fund.)

The comment heading the advertisement reads: "No better translations have so far appeared of Chinese poetry. He has given the real feeling of Chinese poetry, its clarity, its suggestion, its perfect humanity. There is no other translation of Chinese poetry now available with anything like the merit of this. AMY LOWELL." Mr. Knopf did not indicate the ellipsis which he made between the first and second sentences of Miss Lowell's letter to him. The sentence which he excised was: "I have been working lately on Chinese poetry with a friend of mine who lives in China, so I know whereof I speak, and while I do not always agree with Mr. Waley's renderings of those poems with which I am familiar, he has done what nobody else has." Her reservation brings out that she and Florence Ayscough saw themselves as com-

1 The Times Literary Supplement devoted its front page of Nov. 15, 1917 to a review by A. Clutton Brock entitled "A New Planet."

${ }^{2}$ In a review of More Translations, The London Mercury, Nov. I9 19, pp. 79-80. Cyril Connolly included 170 in his list of one hundred "key books," 1880-1950, The Modern Movement, i 966 .

${ }^{3}$ Five letters between Constable and Waley. Temple University Library. 
petitors with Waley, for she and Mrs. Ayscough had been at work since November of I9I7 on a book of translations which was to come out as Fir-Flower Tablets in $192 \mathrm{I}$.

Miss Lowell's interest in Japanese culture was a long standing one, and Florence Wheelock Ayscough (later MacNair) has told, for the two had known each other since childhood, how she introduced her friend to Chinese poetry. ${ }^{4}$ Much of the story of their collaboration and of their opinions of Arthur Waley and his work can be extracted from the collected correspondence of the two ladies: MacNair, H. F. Florence Ayscough and Amy Lowell: Correspondence of a Friendship, Chicago, I 945, and from Foster Damon's Amy Lowell: A Chronicle ... , Boston, 1935 .

Western versions of the classical poetry of China had of course been made before the Imagists seized upon it for their own purpose and made it modish, and before the appearance of Ezra Pound's Cathay in April r $915 .{ }^{5}$ Miss Lowell's schism with Pound, after which she seems studiously to have ignored him, at least in print, also preceded Cathay. For example, she declined as late as 1917 to contribute to The Little Review while Margaret Anderson gave space in it to Pound and Lewis. So Mrs. Ayscough's timely arrival with the proposal to collaborate in Fir-Flower Tablets gave her an opportunity to promulgate Pound's shortcomings ${ }^{6}$ more widely than simply in her correspondence and thus - good publicist as she was-to remain in the van of the modern movement in American poetry and continue her efforts to take over Imagism, rebaptized by Pound as Amygism, in America. But Miss Lowell could not have been expected to welcome the work of other translators like Waley and Bynner, for it meant that she would not be the sole authority in the matter of Chinese poetry and its interpretation.

Waley knew Pound, who persuaded him to send eight translations to The Little Review, which were published in October 1917. Seven more were printed in Poetry for January i9 18, where Amy's poem "The Landlord of the Whinton Inn tells a Story" also appeared. Three more

${ }^{4}$ Ayscough, F. "Amy Lowell and the Far East" The Bookman, Mar. 1926, pp. ro18. See also Amy Lowell's preface to Fir-Flower Tablets.

${ }^{5}$ Pound himself, for example, drew on H. A. Giles's work for Des Imagistes, the ms. of which was dispatched before he received the Fenollosa material, the basis of Cathay.

${ }^{6}$ She realized that any criticism of EP would be attributed to pique on her part (MacNair, pp. 38-48), and praised him in a letter to Fletcher (Aug. 16, 1918, quoted by Damon p. 588 ). 
translations followed in February. By September, Florence is commenting from Shanghai on A Hundred and Seventy Chinese Poems (published in England in July), saying that she intends to avoid poems already done by him. ${ }^{7}$ They had previously seen specimens published in The Boston Transcript which Amy airily called "very charming," doubting that Waley had done the research they had.

In February I9I9, Florence's "Chinese Written Wall Pictures" ("English version by Amy Lowell") came out in Poetry, together with an article on translating in which she praises Amy's literal arrangements of the poems. John Gould Fletcher reviewed the British edition of I 70 in the same number too. In the April issue Waley suggested two emendations in the "Wall Pictures," and Florence in a letter of July 8 proposed to reply to his criticism. ${ }^{8}$ Amy on July 29, reacting to Waley, writes that she is now inclined "to sacrifice rhythm and appearance for exactness" in her versions. ${ }^{9}$

Florence was well aware of the work of the sinologists-who are called generically the Sins-and their lack of poetic sensibility. She refers among others to Hervey-Saint-Denys, L. C. Hopkins, Evan Morgan, H. A. Giles and Sir James Lockhart, the latter two as well as Waley coming in for some hard knocks. But Waley's expertise both ladies now take seriously in spite of his "howlers." They resolve to stay away from "brick-throwing," though, which Florence characterized, like Waley, as the "curse of sinology."10

Work continued meanwhile on Fir-Flower Tablets. Amy writes to Florence in August: “. . . but if this book is to be done at all before everybody else does it - for Chinese poetry is much in people's minds at present, largely owing to Waley-we must work hard and work quickly." She ensured that some of their poems were printed in magazines during the summer of 192 I to prepare the way. Florence, who had visited Waley in London, reported unfavorably, calling him a strange

7 They later changed their minds on this.

${ }^{8}$ MacNair, p. 68, but nothing seems to have transpired.

${ }^{9}$ Ibid. p. 70 .

${ }^{10}$ Ibid. p. 82.

${ }^{11}$ Ibid. p. 76. After the publication of Waley's More Translations in the U.S. in Sept. I9I9 (Fletcher reviewed it in The Dial in Feb. 1920), she changed her mind about the need for haste (MacNair p. 109), only to reverse herself again in the summer of I92I on hearing that Witter Bynner was completing his Jade Mountain. Some specimens of his work had appeared in The Little Review for March 1920 and more came out in Poetry, Feb. 1922. 
being, "most la-de-da" and absolutely sure of himself in every particular. She envied him his assurance. ${ }^{12}$

Houghton Mifflin published Fir-Flower Tablets just before Christmas of $192 \mathrm{I}^{13}$ and Waley's review of it, which the two women had awaited with some trepidation, appeared in the Literary Review of The New York Evening Post for February 4, 1922. He called it "a real book of Chinese poetry" and criticized it because, he said, "it is worth criticizing." The method of collaboration between student of Chinese and poet which Amy described in her preface as essential because of the difficulty of the language, ${ }^{14}$ he dismissed, characteristically for him, saying: "Any one of decent abilities could learn to read Po Chü-i (an easy poet) in a year, and in three years ought to be able to read any poetry whatsoever, together with all necessary encyclopaedias and commentaries. . ." He commented on Mrs. Ayscough's limited knowledge of the literature, history and geography of China and noted Miss Lowell's weak rhythms. Writing that he felt rather a brute (sic) in criticizing Mrs. Ayscough's work, for she had made complimentary references to his own translations, he ended by saying that he has had the courage to twist slightly Miss Lowell's lioness's tail much as he admired many of her versions.

Amy sent a copy of the review to Florence with two long letters, written on successive days, giving her collaborator detailed instructions for a reply to Waley. ${ }^{15}$ She reproached him, for example, with having no sense of humor and not understanding irony (attributing these lacks to his being German[!]), and ended by instructing Florence "above all things [to] pitch into Waley for thinking that Giles's translation of 'Night Thoughts' is nearer the original than mine." For the lioness, ever sensitive to slights and seeing intrigue everywhere, did not appreciate the most minor twisting of her tail. She decided to take up the matter of a comment (which she called ludicrous) Waley had made on the prosody of the $f u$ herself, due to his regrettable ignorance of the nature of polyphonic prose-in which she had a proprietary interest-and enclosed a copy of her letter to the editor on the subject. ${ }^{16}$

\footnotetext{
12 Ibid., p. 125. Waley, recognizing the need to correct the generalizations he had made in $\times 918$, wrote a new introduction to 170 in 1960 .

${ }^{13}$ Constable, who had published $r 70$, imported sheets for the British edition.

14 Florence had already stated this in "Wall Pictures."

15 MacNair, pp. 182-89, I 6 and 17 Feb. 1922.

${ }^{16}$ Burton Watson, a "Sin" of a later generation, obviously did not share her views,
} 
Nevertheless she concluded that Waley's review would be beneficial to them as coming from "a rival translator," and mentioned Houghton Mifflin's "splendid advertisement" in the March Dial. ${ }^{17}$ The half page taken by the publisher consisted of quotations from Le Gallienne's review in The New York Times and four carefully chosen snippets from the one by Waley where, thanks to the time-honored practice of the selective use of ellipsis, readers were given an impression of the book which certainly did not reflect the reviewer's opinion of it. So if Miss Lowell was quoted as an authority in I9I9 in support of Waley's work it was a little ironic, given the reservations each had about the other, that Waley's authority, after the success of 170 , was used in such cavalier fashion to further the fortunes of Fir-Flower Tablets.

The carefully written letter to the editor duly appeared, giving Waley his lesson on polyphonic prose, and, as he did not reply to it, Amy at least was satisfied that he could not. ${ }^{18}$ The two agreed, after Florence's doubts about her replying to the review, that she should not do so, and there the matter seems to have rested. However, Florence made some pungent comments later in the draft of a review of The Temple (published in October 1923), and which she communicated to Amy, writing, "I don't suppose that Waley himself would lay claim to being a poet, nor to being a writer of great merit." She took him to task for writing gibberish and for coining the word "quogged."19

I70, More Translations and Fir-Flower Tablets were treated together by a Chinese writer in a review article called "The Vogue of Chinese Poetry." ${ }^{20}$ Chang Hsin-hai noted the recognition of the potency of oriental influence on the new poetic insurgents - the practitioners of "vers libertines"-and regretted the use of the Chinese poets in support of these new theories of poetry. He attacked Waley's generalizations in his introduction as too categorical, deplored a wordiness and lack of

for he dedicated his book, Chinese Rhyme-Prose, $197 \mathrm{I}$, devoted to poems in the $f u$ form, to the memory of Arthur Waley. In The Temple (1923), Waley discussed the $f u$ at greater length and corrected the remarks he had made in $r 70$.

${ }^{17}$ Malcolm Cowley, reviewing FFT in the May Dial calls Pound and Waley "the enemy," whose versions Ayscough and Lowell successfully challenge in what he called a skirmish.

${ }^{18}$ Literary Review Neqw York Evening Post, Mar. 25, 1922, p. 538, in which she changed slightly the position taken by Florence in FFT p. lxvi. See MacNair p. 187 .

${ }_{19}$ Nov. 15, 1923, MacNair p. 221. The Temple p. 107. Waley later changed "quogged" to "quaked."

${ }^{20}$ Edinburgh Review, July 1922, pp. 99-I I4. 
simplicity in both Lowell and Waley, and said that Waley's knowledge of the language was not fully adequate, while recognizing his accuracy and closeness to the original. The emphasis on component radicals by Ayscough-Lowell puzzled him, ${ }^{21}$ but he concluded that the versions in the three books were "the best translations so far produced of some of the most representative Chinese poets."

The competition over translation of Chinese poetry did have a sequel. This time a Japanese novel was the subject, for when Knopf, who in addition to publishing More Translations and The Nö Plays as well as importing sheets of The Temple, ${ }^{22}$ turned down his proposal for The Tale of Genji, Waley wrote to Miss Lowell asking her to support it with Houghton Mifflin, his next choice of publisher for the book in America. The firm had in 1920 published Diaries of Court Ladies of Old Japan by Annie Shepley Omori and Kochi Doi, and he reminded her that in her preface to that book she had mentioned the desirability of a sympathetic translator for Murasaki's novel..$^{23}$ Houghton Mifflin took sheets of all six volumes of Allen and Unwin's edition which started publication in May 1925; and they did the same for The PillowBook of Sei Shonnagon (1928), which followed the fourth volume of Genji. The collected edition became a publishing success and fifty years later, when the time had come for a new generation to make its own translation, it was Knopf's imprint which appeared on Edward Seidensticker's complete version in 1976 .

Inevitably, the judgments of the makers of Fir-Flower Tablets about Waley's qualities as poet and translator could not be objective. Their book did not eclipse 170 as Miss Lowell had hoped, nor did it advance her efforts to be acknowledged as the leader of the modern movement in American poetry. And it was 170 which was the effective beginning of Waley's multi-faceted career, the ramifications of which were such that the acknowledgement of him by those who came afterwards as the originator of the modern school of translators from Chinese and Japanese recognizes only the central part of the whole body of his work.

${ }^{21}$ Witter Bynner ("Translating Wang Wei," Poetry, I922, pp. 272-78), incurred AL's displeasure by calling attention to the perennially attractive fallacy that Chinese is ideographic rather than logographic.

${ }^{22}$ Knopf reprinted AL's blurb for ${ }^{1} 70$ on the verso of the half-title of The $N \bar{o}$ Plays, 1922 !

${ }^{23}$ Letters of Dec. 28, 1924 and Jan. 24, 1925, Houghton Library, Harvard University. 